\title{
The possible impact of Reformed theology on education as a science, with special reference to the situation in South Africa (1940-)
}

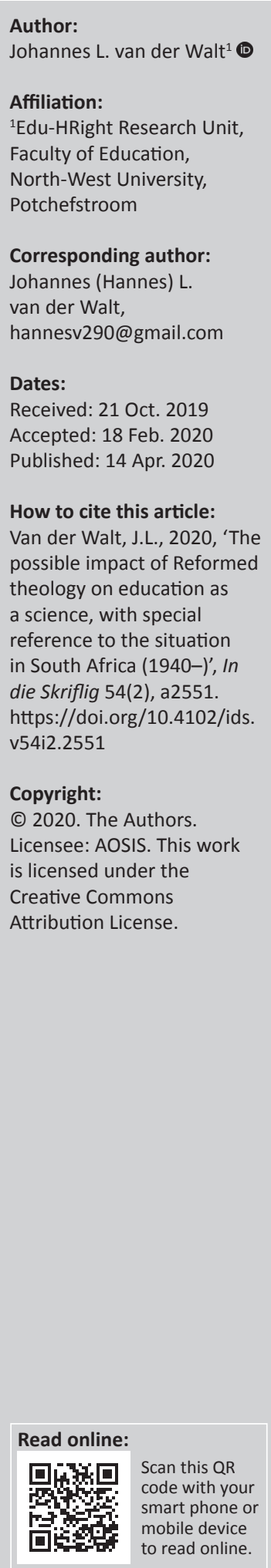

The research reported in this article focused on the possibility of reformational theology having an impact on Education as a scientific discipline. Based on an interpretivist-constructivist theoretical approach and with the aid of a hermeneutic that differentiates between three manifestations of theology (Theology as a discipline in its own right, philosophic theology as a branch of Philosophy and personal theology as part of a personal world and life view), and also based on an overview of the history of education, particularly in South Africa between the 1940s and 1990s, it is tentatively concluded that Theology as a discipline seems to have had only an indirect impact on Education as a scholarly discipline; educationists, particularly philosophers of Education, occasionally immersed themselves in philosophical theology as part of their subject philosophy. Educationists have also seemed to have taken cognisance of the impact of their own and educators' personal theology as part of their personal world and life views.

Keywords: Theology; Reformational theology; Christian scholarship; Education; Subject philosophy; Life and world view.

\section{Introduction}

Education is a relatively new science, dating back to 1809, when J.F. Herbart (1776-1841) began occupying the chair formerly held by Immanuel Kant at Königsberg, and established and conducted a seminar in pedagogy until 1833. Prior to this time, it were philosophers, theologians, novelists and dramatists as well as practical educators such as Plato (428/423-348/347 BC), Augustine (354-430), Comenius (1592-1670), Rousseau (1712-1778) and Pestalozzi (1746-1827) who wrote about people, communities and education in various contexts. Close analysis of the phenomenon of education and the formation of theories only followed after the groundbreaking work of Herbart. Part of the history of Education as a science is the story of its constant struggle to assert itself as a separate and recognised scholarly discipline, even to this day. ${ }^{1}$

In part, Education's struggle for recognition as an independent discipline can also be ascribed to the fact that everybody regards himself or herself as an 'expert' on education, having themselves been educated for 18 years by their own parents and for 12 years by school teachers, and possibly having brought up children of their own. The views held by the general public and by scholars in other disciplines have resulted in a view that persists to this day, as Labaree (1998:4-11) famously demonstrated, namely, that the knowledge produced by educational researchers is a form of 'soft' knowledge as opposed to the so-called 'hard' knowledge of the more supposedly exact sciences, that educationists produce applied, practical and practitioner-serving knowledge, that their claims are value- and purpose based, and that the norms and values of the researchers as well as those of the social actors who are being researched play a role. Such views could also be ascribed to the fact that educationists tend to engage with a wide range of pedagogical phenomena, ranging from babyhood (pedagogy) through adulthood (andragogy) to old age (gerontagogy), and that the knowledge they produce is non-esoteric, in the sense that the field is wide open to

\footnotetext{
1.This struggle for recognition as a separate and independent subject lasted for a relatively long time after Herbart's appointment. Phillip Abraham Kohnstamm, for instance, was appointed as special professor of Education in 1919 at the Free University of Amsterdam under the instigation of the Maatschappij tot Nut van't Algemeen [Company aimed at the well-being of all], and not based on the fact that a specialist educationist was needed at the university. Miedema's (2016:4) depiction of Kohnstamm's contribution to Education illustrates how he tended to infuse Education with Theology because of his advanced training in both disciplines: 'Kohnstamm's Biblical personalism amounted to a form of pedagogics that was intrinsically charged with Christian theological thinking and form giving by a man with a amounted to a form of pedagogics that was intrinsically chas 's ision, by which I have been increasingly inspired regarding a strong personal Christian faith'. Elsewhere he states: 'Konstam's vion, by which have ben increasing insping the relationship between Pedagogics and Theology, is a valuablo This fusion of disciplines was continued when Jan Waterink was appointed as professor of Pedagogics and Didactics in 1926 in the Faculty of Humanities as well as extraordinary professor of Catechetics. The initiator of his professorship, the 'Gereformeerd Schoolverband' [Reformed School Association], had hoped for a specialist educationist but this did not materialise with the appointment of Waterink, who had also acquired a doctorate in Theology on Calvin's catechism (De Muynck 2017:120).
} 
amateur educationists and to discursive critique from nonexperts in education. It is clear from this brief sketch of the history of the subject and its current status that the struggle of Education science (pedagogics) is not yet something of the past. Education, most likely, never will be able to avoid contact with, and hence possibly also influence from, other branches of knowledge or scholarship, including Theology.

This article was prepared in response to a call for papers on the issue of whether Reformed Theology might have had an impact on other fields of scholarly enterprise, a call for purposes of a conference held as part of the 150th year celebration of the Reformed Church's Theological Seminary in Potchefstroom, held in September 2019. The following research question was formulated in response to the call: what impact, if any, has Reformed Theology had on Education as a science?

\section{The research method applied for arriving at an answer to the research question}

An interpretivist-constructivist approach was applied as hermeneutic, an instrument for understanding and explanation (Aldridge 2018:245-246). The interpretive phase of the method entailed examining the world of human experience as far as it affected educationists (Education scholars) and the possible impact that Theology as a science might have had on them and their scholarly work. Interpretivists depart from the notion that social activity, including scholarship, emerges from intentional action and interaction at the individual level, in addition to other internal and external causal factors (Packard 2017:536). As, as interpretivists contend, scholarship is not conducted in a deterministic sense, but as a chosen course of action towards the subjective end of the person (scholar/ educationist, in this case) (Packard 2017:537), multiple perspectives in connection with the research problem were gathered, both in the form of literature studies and personal interviews. This was done in an effort to gain in-depth insights into the issue of whether Reformed Theology, indeed, might have had an impact on Education as a field of scholarship, and if so, to what extent. The interpretivist phase provided the context described and discussed in the remainder of this article (Thanh \& Thanh 2015:24-26). It should, nevertheless, be kept in mind that educationists, like all social scientists, can only make tentative and contingent claims that could be difficult to sustain in the face of alternative claims by scholars following different interpretive approaches (Blackburn 2017:76; Labaree 1998:5, 6).

Closely associated with interpretivism is constructivism (Thanh \& Thanh 2015:25). Constructivism as a scholarly method or approach to a problem is based on the assumption that reality and the human behaviour therein are characterised by continuous fluctuations, adjustments and transformations operating simultaneously at multiple sites and that they offer a subtle depiction of how facts emerge and 'truths' are shaped. Jensen (2019:4/29) concurs with Plotnitsky (2006:52) who contended that scholars are dealing with a heterogeneous yet interactive space of relationships, where differences, similarities and interactions are all found, but each becomes more or less crucial at different conceptual, historical or cultural junctures. Scholars (in this case, educationists) work in a dynamic space-time or 'a sea of energy of thought, a space at the edge of chaos', according to Jensen. Labaree (1998:11) quipped as follows in this regard: ' $[t]$ here is nothing like confusion to create opportunity'. Scholarly reflection and theoretical construction enable the scholar to find a way through this maze. Based on the data gathered regarding the research problem, and particularly the interpretations thereof, a picture was constructed on the basis of which a number of tentative conclusions regarding the research question could be drawn.

As mentioned below, the investigation would have been unmanageable if it had not been delimited. Finding answers to the question of whether Reformed Theology might have had any impact on the theory and practice of Education as a science in general and also worldwide would have been unfeasible. In view of this, reference is made in passing to situations elsewhere around the world where Reformed Theology arguably might have (had) a strong(er) impact on Education. The main focus in the following is on the situation in South Africa, particularly from around the 1940s, when most faculties of education were established in universities, up to the early 1990s, with the advent of the 'new' South Africa that brought about a sea change in the educational landscape of the country.

\section{Education and its ancillary disciplines}

Education, as opposed to other special sciences that tend to gain access to their fields of inquiry or study objects through one particular modal aspect of reality, could be regarded as a 'thing' or phenomenon-based and phenomenon-directed science. It accesses the education phenomenon not solely through one modal aspect of reality but teases it out from the entirety of human existence. As education as a phenomenon functions in all aspects (modalities) of human existence, a responsible understanding of the nature of education requires a multi-disciplinary approach (Strauss 2009:53). Despite the fact that education should be approached in a multi-modal and multi-disciplinary manner, it remains focused on a single phenomenon or object of study, subject to its own 'thing' or ontic laws (in this case, education laws, norms and values) that guarantee its uniqueness amongst the great diversity of things in reality (Taljaard 1976:49).

This multi-modal, multi-disciplinary and 'thing' or phenomenon orientation of Education as a science has over the years made it susceptible to undue influence from, and occasionally also encroachment by, the other disciplines on which Education depends to come to a proper understanding of its object of investigation. Its object of investigation is in itself very diffuse, which is difficult to describe, 
delimit and delineate (Labaree 1998:5). The following is an approximation of the meaning of the term 'education' in the wide sense of (German) Erziehung: the leading, guiding, aiding, equipping, unfolding, shaping, forming, nurturing and also training of less mature people by others who are in certain respects more mature, and capable of providing such leading, guiding and so on (Nussbaum 2011:23, see also Fowler, Van Brummelen \& Van Dyk 1993:156). The nature of the pedagogical field compels educationists to seek the input and assistance of a variety of ancillary disciplines to be able to come to a deep understanding of and insight into all the ramifications of the leading, guiding and so on. This dependence, however, might result in one or more of the ancillary sciences assuming a dominant status vis-à-vis Education as a science, thereby potentially exerting undue influence on the latter. This occurs when the ancillary discipline is regarded as the basic discipline, and Education as the qualifying discipline, as shown in Table 1.

The situation is, of course, exacerbated by the fact that Education as a science is normally not practised for its own sake, ${ }^{2}$ but as the foundational science of teacher education, the education of lecturers at tertiary education (higher education) level and of the education of trainers in industry. The net effect of this complex configuration is that Education as a science could become so intertwined with other disciplines that educationists (scholars) occasionally have to deal with so-called subject boundary issues (issues regarding the encyclopaedia of disciplines). This can be illustrated with reference to the recent discussion about Law in Education. According to Oosthuizen (ed. 2011:20), some educationists remain content with seeing it as 'a new field of law', part of administrative law. Oosthuizen (ed. 2011:20-21) himself prefers to regard it 'as a separate field of study, ... not to be classified in the general legal field of study'. He then offers a number of arguments in support of this view, but then nevertheless continues referring to the field as 'Education law', and regards it as an interdisciplinary field of study.

It is clear from the above that Education finds itself in a constant struggle to define, delimit and assert its own boundaries as a discipline in its own right, and that it constantly has to deal with the predicament of having to consult its ancillary disciplines while guarding against possible domination by one or more of these ancillary disciplines. As mentioned in Table 1 footnote, Theology does not appear in the table as one of the ancillary subjects of education. This can arguably be explained in terms of the interpretive framework proffered below.

\section{The relationship between Theology and Education}

The following interpretive framework (hermeneutic instrument) provides insight into the relationship between

2.There might be exceptions to this, for instance, when somebody takes the subject for his or her own edification and not necessarily to become a teacher or a lecturer Education is occasionally also taken as an ancillary subject, for instance, when practitioner such as a social worker requires more insights into juvenile behaviour.
TABLE 1: Education as basic discipline versus Education as qualifier.

\begin{tabular}{ll}
\hline $\begin{array}{l}\text { The ancillary discipline as basic } \\
\text { discipline, with Education seen } \\
\text { as qualifier }\end{array}$ & $\begin{array}{l}\text {...As opposed to Education as the basic } \\
\text { discipline, and the ancillary discipline } \\
\text { as qualifier }\end{array}$ \\
\hline Educational philosophy & Philosophy in/of education \\
Educational history & History of education \\
Educational economy & Economics in education \\
Educational psychology & Psychology in/of education \\
Educational management & Management in education \\
Educational or education law & Law in education \\
Educational sociology & Sociology in/of education \\
\hline
\end{tabular}

Note: Theology does not appear in this list because it does not fulfil an ancillary role in and for education as such. It, however, forms the background science for one of the subdisciplines of curriculum studies, namely, the subject didactics of religious or religion education and religious instruction. In South Africa, students taking this subject have typically majored in Biblical or religious studies in their undergraduate years (cf. Aldridge 2018:245), and not in theology as such. There have been exceptions to this rule, for instance, when a person who has trained for church ministry decided to become a school teacher.

Theology/theology and Education as a science. ${ }^{3}$ According to the framework, we could differentiate between three interrelated concepts of 'theology':

- Theology as a scholarly discipline or subject in its own right, with all its sub-disciplines, as practised, for instance, at a Theological Seminary or a Faculty of Theology at a university.

- Philosophical theology, a sub-discipline of philosophy, a branch of philosophy that formally, systematically and scientifically examines a scholar's assumptive values, views and principles about God or the divine that might be playing a background role in how a particular scholarly discipline (such as Education or Theology) is approached, practised and understood (Strauss 2009:65). Reflection about such issues normally forms part of the subject philosophy of the special science in question (in this case Education). In the case of Education, the subject philosophy customarily goes by the name of 'Philosophy of Education' or 'Fundamental Pedagogics'. The contents, character and nature of a special science philosophy depend on the life and world view perspective of the

3.1 came to the conclusion that 1 had to develop and apply an interpretiveconstructivist hermeneutic after a discussion with a professor of Economics at the University of South Africa who had completed his studies at the former Potchefstroom University for Christian Higher Education. When I told him what my paper at this conference was about, he responded with: 'Oh, that's easy! Everything at the old PUK was theology! There were subjects such as Life- and Worldview Studies, Ethics and Logic, Philosophy of Economics, Studium Universale and so on in my Faculty. Even in the other subjects, the lecturers contrived to bring theology into the fray!' His response convinced me that many pop the fray! His response convinced me that many people were under the impression that attempts to bring the Christian or Biblical life- and worldview to bea

This impression was subsequently reinforced after examining the professorial inaugural speech of De Muynck and of publications flowing from it (De Muynck 2017). De Muynck finds himself in the situation of being at the same time an educationist at a Pedagogical University (Gouda, The Netherlands) and an extraordinary professor of Christian Pedagogics at the Theological University Apeldoorn (The Netherlands). Because of this dual appointment, his views of Christian education seem to vacillate between the notion of Education as separate, independent discipline, and Education as an ancillary science of Theology, particularly Practical Theology, and vice versa. Following Miedema (2016) he saces the relationship between these two disciplines as complement (2016), he sees the relationship between these two disciplines as complementary (De Muynck 2 disciplines.

Miedema's (2016) scholarly position differs from that of Kohnstamm and Waterink in that he was an out and out educationist and not trained in both Education and Theology. His position also differed from that of De Muynck in that he, as an out and out educationist, did not have to ply his trade in an education university and a theological university at one and the same time. He nevertheless seems to be agreeable to the stances taken by Kohnstamm and De Muynck in that he see Education and Theology as potentially complementary disciplines (Miedema 2016:6) Cok Bakker represents a third position, namely, that of a theologian or religious Cok Bakker represents a third position, namely, that of a theologian or religious educationist occupying a chair in Education in a Faculty of Humanities, namely at the Universty of Utrecht, The Netherlands. His training was in Theology/Religious Studies. As professor of Life and Worldview studies [Levensbeschouwelijke vorming] in the Department of Philosophy and Religious Studies at the Faculty of Humanities, he has a three-way perspective: theological, humanities and education. 
philosopher in question. When this orientation is Christian or Biblical, one could speak of a 'Christian Philosophy of Education'.

- Personal 'theology', an informal, pre-scientific and pretheoretical aspect of every person's personal and social life and world view. 'Theology' in this informal pre- and post-scholarly (theoretical) sense refers to a person's or a group's deepest convictions about the divine in their lives and existence. As Van der Walt (1997) explains, it forms part of an:

[I]ntegrated, interpretive, normative (system of) beliefperspectives on reality (in this case, the divine as part of the reality that the person experiences - author) that root, form, motivate, give direction and meaning to the human being, thereby outlining his or her calling in the world. (p. 47)

Tripp (2010:108) refers to 'theology' in this sense when he speaks of a person's personality, tastes, politics, theology, family, history and dreams of the future. In all forms of scholarship, this aspect of a scholar's life and world view tends to be in line with the second notion of theology above.

These three meanings of the concept 'theology/Theology', if not clearly differentiated, could cause confusion. For example, when an educationist critical of a Christian reformational approach to education notices a colleague operating on the fundamental basis of a Christian reformational philosophy and life and world view (the second and third categories above), he or she might incorrectly suspect the latter of working from the fundamental basis of reformational Theology (the first category), instead of allowing the education phenomenon to speak for itself. During the 1970s and 1980s in South Africa, this has repeatedly occurred during exchanges amongst Christian reformational educationists and those who operated on the basis of a phenomenological or a positivistic approach to education. The author of this article frequently witnessed the latter accusing the former of deriving their pedagogical categories and perspectives from reformational Theology or even directly from the Bible. They mentioned, for instance, that Coetzee had taken cognisance of the ideas of Herman Bavinck and suspected him of deriving the pedagogical categories from either the Bible or Theology, or both, and not from the phenomenon of education as such. They accused him and his successors of approaching education as a phenomenon 'from a Christian-particularistic-life conceptual approach and that his contributions to education were more prescriptive than descriptive' (Van der Walt \& Du Toit 1992:4, 35; see also Malan 1986; Coetzee n.d.:3, 9). ${ }^{4}$

There are a great number of universities and colleges across the world that, to a greater or lesser extent, practise Education as a science from a Christian reformational perspective, some of them even intentionally and devotedly from a Christian theological perspective (the first category), such as the Károly Gáspár University of the Reformed Church in Hungary. (Its former name discloses much of the orientation of this university: The Reformed Theological Academy of Budapest).
Much the same can be said of the Sárospatak CalvinistReformed Theological Academy in Hungary, and also of Calvin College, an institution that practises Education as a science under the auspices and management of the Synod of the Christian Reformed Church of North America. Dordt College is likewise affiliated with the Christian Reformed Church in North America. Although the Driestar Educatief University for Teacher Education in the Netherlands is not formally associated with any church, it has close links with the Hervormde Kerk. Something similar applies to the Kosin University in Korea (South), which is closely affiliated with the Kosin branch of the Presbyterian Church. University officials are, for instance, accountable to the church, and the university is largely funded by the church. A closer investigation is required for coming to a conclusion about the extent to which Theology as a scholarly subject (the first category) indeed might have had an impact on the activities of such institutions of higher learning, particularly with reference to teacher education and the practice of Education as a science.

A careful differentiation between the three categories of Theology/theology outlined above is fundamental to the understanding of the possible contributions of Theology/ theology to Education.

In the remainder of this article, our attention is restricted to the situation in South Africa in the period from the 1940s to the early 1990s.

\section{The Christian National Education theme}

The pre-1994 apartheid education policies of the government complicated the education picture in South Africa in that it cast a contentious concept into the fray, namely, 'Christian national education'. ${ }^{5}$ Coetzee (1968) and particularly Bingle, his successor as professor of Theoretical Education, were spokespersons for this approach to education (Bingle 1953; Schutte 1978b:187-187; Van der Walt \& Du Toit 1992:4, 36).

Space does not allow a detailed history of how this ideology unfolded and was put into practice in South Africa. It suffices to say that it brought about serious repercussions for the nonAfrikaner segment of the pre-1994 population of South Africa.

As part of the broad 'separate development' policies of the government at the time, the Bantu Education Act of 1953 terminated the pre-1948 system of control of education in South Africa: education or schooling for white people was henceforth managed by the Minister of Education (Barnard 1979:140; Barnard \& Coetzee 1975:179), while education for black people, people of mixed race and Asians was provided, financed and controlled by missionaries and other non-governmental organisations, and managed by separate education departments. As a result of the Act, the

5 This term is variously written Its proponents tend to write 'Christian national

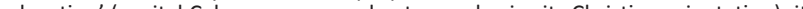
education' (capital $C$, lowercase $n$ and e, to emphasise its Christian orientation); it opponents either write "Christian National education" or "Christian National Education' (in both cases with a capital $\mathrm{N}$ to underscore this political element as the driving force behind apartheid). 
TABLE 2: Education staff at some universities in the 1980 s.

\begin{tabular}{|c|c|c|c|c|c|c|}
\hline $\begin{array}{l}\text { University of } \\
\text { the Free State }\end{array}$ & $\begin{array}{l}\text { Potchefstroom University for } \\
\text { Christian Higher Education }\end{array}$ & University of Pretoria & University of South Africa & Stellenbosch University & $\begin{array}{l}\text { University of Port } \\
\text { Elizabeth }\end{array}$ & $\begin{array}{l}\text { Rand Afrikaans } \\
\text { University }\end{array}$ \\
\hline J. De W Keyter & J.C. Coetzee & C.K. Oberholzer & C.B. Swanepoel & C.F.C. Gunter & J.J. Pienaar & P. Van Zyl \\
\hline J.J. Fourie & H.J.J. Bingle & W.A. Landman & D.J. Greyling & C.G. De Vries & J.M.A. Kotze & D.P.J. Smith \\
\hline P.G. Schoeman & B.C. Schutte & S.J. Gous & T.A. Viljoen & J.C. Steyn & R. Grebe & J.J. Smith \\
\hline O.A. Henning & J.H. Van Wijk & T. Moller & G.J.C. Killian & - & P. Smal & - \\
\hline J. Van der Linde & J.L. Van der Walt & S.G. Roos & G.C. Van Vuuren & & S. Van Rensburg & \\
\hline- & - & G.J. Joubert & O.J. Van Schalkwyk & - & - & - \\
\hline- & - & F.J. Stuart & H.J.S. Stone & - & - & - \\
\hline- & - & F. Van der Stoep & E.J. Van Niekerk & - & - & - \\
\hline- & - & M.C.H. Sonnekus & - & - & - & - \\
\hline And others & And others & And others & And others & And others & And others & And others \\
\hline
\end{tabular}

ex-missionary institutions that had not been closed during the transfer of control to the State were put under the control of principals and teachers who were committed to the ideologies of apartheid and to Christian-national education/ Christian-National Education (CNE) (Hartshorne 1993:197; cf. Van der Walt 2019:226). According to Christie and Collins (1984:162; cf. Van der Walt 2019:226), this change in policy negatively affected the Christian ideals of an egalitarian and communal society in which everyone aspired to a common culture that was both Western and Christian. While the syllabuses (of the different school, college and university subjects) for non-whites, as such, allowed alternative interpretations, both the textbooks of this period and the teachers were strongly biased toward the CNE approach (Hartshorne 1993:243; cf. Van der Walt 2019:226).

The move to Bantu education based on the 1953 Act was opposed by the non-Afrikaner segment of the population, particularly the so-called non-whites, the English-speaking missionaries who controlled some of the schools, and also the white and black teachers who taught in them. They particularly objected to the indoctrination that coincided with CNE. The white community was accused of using Christianity (Calvinism) as a reinforcing mechanism to the apartheid creed (Christie \& Collins 1984:161). Christian National Education policies nevertheless remained in force until 1994.

Education for the white individuals amongst the population was regulated by another Act, namely, the Act on National Education Policy of 1967 (Act 39 of 1967), which stipulated that education for white South Africans should be under state control and 'should possess a Christian and a broadly defined national character' (Barnard 1976:8). It embodied the Christian education ideals and aspirations of the white Afrikaner population of South Africa (cf. Bingle 1970:26).

A closer examination reveals that the faculties of education of all of the universities dedicated to the tertiary education of the Afrikaner youth to a greater or lesser extent were staffed by proponents of the ideology of CNE. Table 2 gives an idea of their staff complement during the 1960s to the early 1990s.

Although all the educationists mentioned in Table 2, as far as could be established, were Christians in their personal lives, many of them opted for a phenomenological approach, particularly those at the universities of Pretoria, Stellenbosch, Port Elizabeth and some of those attached to the University of South Africa. Although the phenomenologists aligned themselves with the Husserlian idea of bracketing one's personal life and world view while engaged in scholarly work, some of them regarded the educator's life and world view as an issue to be specifically dealt with. W.A. Landman, for instance, discussed the pedagogical implications of both the Baptismal and the Holy Communion formularies of the reformed faith with his students. He regarded these formularies as post-scientific 'manifestations' ('places of appearance') of the pedagogical essences revealed by the phenomenological method. According to C.C. Wolhuter (pers. comm. [North-West University], 24 July 2019), the reformational life and world view was 'constantly present' in their scholarship, despite their phenomenological approach. This, in fact, according to C.C. Wolhuter (pers. comm. [NorthWest University], 24 July 2019), was the core theme of S.G. Roos' phenomenology. Roos regarded the life and world view as the 'realisation' of pedagogical essences.

In contrast to C.C. Wolhuter (pers. comm. [North-West University], 24 July 2019) who opines that the phenomenologists were never diametrically opposed to Theology as an ancillary subject, F.J. Potgieter (pers. comm. [North-West University], 19 July 2019) holds the view that they were essentially sceptical of Theology as it dealt with God and his revelations, all of which were unexaminable because they lacked onticity. In his opinion, the phenomenologists whom he had encountered were sceptical of Theology because phenomenology was committed to answer the question of the Existenz of onticities (the question regarding the essence or essential features of phenomena). Because God and his revelation do not possess ontic status in the normal sense of the word, they cannot be objects of scientific examination. Humans possess Dasein [being in the world]; God does not possess similar Dasein, and hence cannot be the object of research. By asking the question regarding the Existenz of something, phenomenology becomes ontology. A mantra of the Pretorian phenomenologists, according to F.J. Potgieter (pers. comm. [North-West University], 19 July 2019), was that phenomenology was only possible as ontology. F.J. Potgieter (pers. comm. [North-West University], 19 July 2019) concurs with C.C. Wolhuter (pers. comm. [North-West University], 24 July 2019), however, that the Pretorian phenomenologists regarded the Christian reformational life and world view as pre- and post-scientific 
(and hence that it could be bracketed out when engaging in scholarship - the Husserlian and Von Brentanoian notion of the Einklämmerung of the life and world view). Landman later on (in the late 1980s) conceded that the educationist's life and world view indeed played a role in scholarship, but would not go further than to recognise that it fulfilled a post-scientific role in Education as a science. As post-scientific or posttheoretical aspect of human existence, it can only be examined post-scientifically, for instance, in a classroom where the teacher and student intentionally engage with each other. Without this post-scientific engagement between educator and students, CNE would have been meaningless (F.J. Potgieter, pers. comm. [North-West University], 19 July 2019). According to C.C. Wolhuter (pers. comm. [North-West University], 24 July 2019), the History of Education taught at the former Rand Afrikaans University also culminated in a study of the contributions of reformational educationist Jan Waterink. Van Zyl (1970:62-83), of the former Rand Afrikaans University, also practised a form of Christian philosophy of education (with no reference to Theology as such), but his successors later began developing a 'fruitfulness' (i.e. pragmatic) approach.

While all of the above transpired in the context of the phenomenological approach to education, another group of educationists, particularly those attached to the University of the Free State, the former Potchefstroom University for Christian Higher Education and some of the educationists attached to the University of South Africa, devoted themselves to a systematic exposition of reformational education. According to Bingle (1953), Coetzee was well versed in theology (the first category). A closer inspection reveals that his scholarly work speaks more about a Christian reformational life and world view perspective than a strictly theological one. It speaks about the 'religious-philosophical foundation in which he rooted his work', referred to by Bingle as his 'Afrikaans Calvinism' and by Snyman (1953) as his 'Calvinistic faith and convictions'. Bingle, because of his master's and doctoral studies in Religious Education, immersed himself in Theology (first category), particularly dogmatics (Schutte 1978a:103). One of his more recent successors, Van der Walt, made a sojourn (1969-1970) in the Faculty of Theology at the former Potchefstroom University for Christian Higher Education before returning to the teaching profession, later to become professor in Philosophy of Education at the same university.

Coetzee, Bingle and Schutte developed a philosophy of education based on what Coetzee referred to as the general issues that educationists were called to address, the Foundations of Education (which, to an extent, coincided with the modal approach followed by their Bloemfontein colleagues), and Basic Issues that merited reflection (such as the aim of education, the 'educand', the contents of education, method of educating, discipline, the education system and its organisation). Bingle also attended to the didactics of Biblical studies and took part in the drafting of Act 39 of 1967, which formally embodied the ideology of CNE and set the political educational tone for education until the advent of the 'new'
South Africa in 1994. Schutte, for the most part, based his approach to education on the contributions of Coetzee and Bingle. In the 1970s, Van Wijk and Van der Walt began exploring the possibilities of the Philosophies of the Cosmonomic Idea and of the Creation Idea (Stoker) but not to the same extent as their Bloemfontein colleagues. Later in their careers, they tended to follow a more problem-oriented approach rather than a systematic approach. Schoeman, Henning and Van der Linde of the University of the Orange Free State, and Stone of the University of South Africa, opted for a systematic examination of education in terms of Dooyeweerd's Philosophy of the Cosmonomic Idea. In this, they followed the lead of philosophers such as B. Kok, E.A. Venter, H.J. Strauss and D.F.M. Strauss.

During the period in question, proponents of CNE were appointed at the so-called homeland universities. The names of J.C. Ackerman, C.F. Beyers-Boshoff, A.J. Vos, J.H. Bekker, P. Duminy and D. Gericke (University of Zululand), P.J. Heiberg (University of the North) and R. Grebe (University of Venda) come to mind in this context. The Interdenominational Committee on Education (with delegates from the three Afrikaans reformed churches in South Africa), while not practising Education science as such, also promoted reformational education within the parameters of the official apartheid and CNE policies and ideals of the time (1970s-1990s). The names of J.J. Keyter, G. Gouws, H.T. Van Deventer, B.C. Schutte, H.B. Kruger and J.L. Van der Walt could be mentioned in this context. This committee looked after the pedagogical interests of the three reformed churches but did not contrive to infuse education with Theology (first category) as such.

As discussed in the next section, all this work petered out with the advent of the 'new' South Africa.

At around the same time, the faculties of education of most of the universities that served the English-speaking white community, such as the universities of the Witwatersrand, Cape Town and Rhodes, and also non-governmental organisations that agitated against apartheid education, were mostly staffed by English-speaking educationists who not only entertained a liberal-pragmatic frame of mind but were also caustically critical of $\mathrm{CNE}$ and the general policies of the apartheid government. The names of critics such as P. Kallaway, K. Hartshorne, P. Enslin, W.E. Morrow, J. Hofmeyr, N. Taylor, L. Chisholm, H. Herman, D. Meerkotter, C. Collins, B. Fuller, S. Pendlebury, P. White and others come to mind in this context. Based on their liberal-pragmatic-critical stance, these educationists attacked the apartheid policies, including CNE, wherever possible, and in the process, supported the anti-apartheid strategies of the black population, amongst others, by participating in People's Education during the 1980s (Van der Walt 1987). In doing so, they aligned themselves with the positions taken by the so-called mixed race and black educationists such as P.C. Luthuli (University of Zululand; some of the work on African education and indigenisation by P. Higgs ties in with his), R.E. Van der Ross, J. Gerwel, H. 
Herman (University of the Western Cape), J. Jansen (first degree at the University of the Western Cape, advanced degrees in the United States, later Dean of the Faculty of Education, University of Pretoria and Rector of the University of the Free State), I. Rensburg (later to become the Vice-Chancellor of the University of Johannesburg) and O. Dhlomo (Minister of Education of the former KwaZulu homeland). Some of the educationists in this group, such as Gerwel (pers. comm. [University of Zululand], 01 July 1986), O. Dhlomo (pers. comm. [University of Zululand], 26 June 1986) and P.C. Luthuli (pers. comm. [University of Zululand, Empangeni], 28 June 1986), also suspected the Afrikaner educationists who plied their trade from a phenomenological vantage point of supporting and promoting CNE despite their much-vaunted scientific objectivity and neutrality. These critics of apartheid and of CNE did not accuse their counterparts of applying theological categories (first category) to education, however; they rather accused them of promoting the ideology of apartheid under the guise of CNE.

This configuration of ideological forces in the period from the 1960s to the end of the 1990s made for interesting multilateral discussions amongst the educationists of that period. The discussion was conducted in various configurations amongst the following groups of educationists:

- proponents of CNE with a basic Christian-reformationalBiblical confessional stance ${ }^{6}$

- proponents of CNE with a Christian-reformational stance based on the Philosophy of the Cosmonomic Idea

- proponents of CNE with a phenomenological orientation

- opponents of CNE with an English liberal-pragmaticcritical theory orientation as part of their struggle against apartheid

- opponents of CNE amongst the upcoming black educationists, as part of their offensive against apartheid.

\section{Advent of the 'new' South Africa in 1994}

The coming of the 'new' South Africa in 1994 put an end to the exchanges amongst the Afrikaner educationists about whether a Christian reformational approach to education could be acceptable in scholarly terms, or whether the phenomenological bracketing of the scholar's life and world view could be justified. It also terminated the criticism of CNE from the side of the English liberalpragmatic-critical educationists and from the black proponents of a new political dispensation in South Africa, for the simple reason that the old apartheid education dispensation had been replaced after 1994 with an altogether new education system that all educationists in South Africa, irrespective of their pre-1994 ideological backgrounds, had to come to terms with (Curriculum 2005

6.One of the reviewers of this article suggested that "Opponents of CNE with a Christian-reformational stance based on the Philosophy of the Cosmonomic Idea' should also be included in this list, either as a sub-category of this group or as a separate group. up to the current Curriculum and Assessment Policy Statement [Department of Basic Education 2011]). The arrival of the new South Africa rendered the entire pre-1994 pedagogical discourse irrelevant.

Reflection about Christian reformational education has now vanished from the public education arena. Some of this activity has now migrated to private institutions such as the Akademie Reformatoriese Opleiding en Studies (AROS) and other non-governmental organisations and institutions. All the public universities in South Africa, including the North-West University, have for all intents and purposes become secularised institutions. Only traces of Christian reformational Education science can still be detected, as evidenced by articles occasionally published in Koers, Journal of Humanities, In Luce Verbi, Journal for Christian Scholarship, and now and then in the Journal of Research in Christian Education and Christian Higher Education. Some educationists continue associating themselves with the International Association for the Promotion of Christian Higher Education (recently renamed as the International Network for Christian Higher Education) and still attend its conferences. Others persist with long-standing relations with Christian reformational institutions such as the Driestar educatief in the Netherlands, Calvin College and Dordt College in the United States, the Károly Gáspár University of the Reformed Church in Hungary, the Sárospatak Calvinist-Reformed Theological Academy in Hungary, the Kosin University in Busan, South Korea and others.

The current discourse on Education in South Africa seems not to be so much about religious and life and world view orientation as it is about educational reform, and the role of the government and of the two departments of education therein. Topics such as the following are now being researched: human rights, democracy and education, citizenship issues, diversity, health and well-being, future careers, globalisation, glocalisation, neoliberalism and neocapitalism, decolonisation, indigenisation, postmodernism, post-foundationalism, post-post-foundationalism, selfdirected learning, education reform, teacher education for the new conditions, self-directed learning and many more (cf. Nel 2019). Whatever philosophical reflection still occurs in faculties of education nowadays is conducted under the headings of Foundations of Education, Life Orientation and Life Skills, subjects that cover a wide array of basic issues in education, particularly with respect to teacher education.

\section{Tentative conclusions}

The investigation reported in this article seems to suggest the following in terms of the three categories of Theology/ theology outlined at the beginning.

- Firstly, with regard to Theology as a scholarly discipline or subject in its own right, with all its sub-disciplines, as practised, for instance, at a Theological Seminary or a 
Faculty of Theology at a university, three sub-conclusions could arguably be drawn.

- The first is that there seems to have been a degree of formal acquaintance with Theology as a discipline on Education as a separate scholarly discipline. Coetzee had familiarised himself with the Theology of his time, Bingle studied Theology, particularly dogmatics, for purposes of his advanced degrees in Religious Studies, and Van der Walt made a sojourn in the Faculty of Theology of the former Potchefstroom University for Christian Higher Education. A more direct impact of Theology has probably been exerted on Education at universities with a strong theological focus, such as the Theological University of Apeldoorn or the Sárospatak Calvinist-Reformed Theological Academy. In such cases, Education clearly performs a supportive or ancillary function for disciplines in Practical Theology.

- Informal influence might have flowed from theologians to educationists in the course of their normal academic work (cf. J.J.M. Verhoef, pers. comm. [Potchefstroom University of Higher Education], 19 July 2019). The theologians of the faculties of theology at the universities of Pretoria, Potchefstroom, Bloemfontein and Stellenbosch have been in constant contact with their counterparts in other faculties, for instance, during Senate, Faculty Board, Executive Committee and other meetings and in all kinds of induction courses for academics and during social gatherings. (To some extent this might also be true of the educationists working at the University of Fort Hare. The university started out as the Lovedale Missionary Institute and had a massive influence on black academics and political actors in the period before 1994. It has, however, never instituted a Faculty of Theology.) There was also a relatively lively academic exchange between scholars, including educationists, attached to Potchefstroom University and the Free University of Amsterdam, the Netherlands, up to the imposition of a cultural embargo on South Africa in the late 1960s. Such exchanges might have had an influence on the work of the educationists in question. Van der Walt and his colleagues have furthermore, from the mid-1970s up to today, maintained contact with De Muynck, his predecessors and his colleagues at the Driestar educatief, Gouda, the Netherlands. Keep in mind De Muynk's dual position as educationist at the Driestar educatief and as extraordinary professor of Education in the subject group Practical Theology at the Theological University of Apeldoorn (see footnote 3). Van der Walt cum suis have also maintained contact with Miedema, a scholar who has shown a strong affinity for incorporating theological insights in education, as explained in footnote 2. All these interactions might have had influence on the work of the educationists involved, but this will obviously be difficult to quantify.
- There is sufficient documentary evidence, for instance, in the form of the literature that they consulted (Coetzee 1965: Bibliography, for example) and on the basis of personal exchanges with them, to assume that in the period under investigation many of the educationists would have acquainted themselves with the works of theologians such as Augustine, Luther, Calvin, Kuyper, Erasmus, Bavinck, Berkhouwer, Berkhof, Kierkegaard, Bonhoeffer, Niebuhr, McGrath, Rahner, Brueggeman, Schaeffer, Schillebeeckx, Robinson, Jablonski, Stiles, Gilson, Barth, Jaspers, Brunner, Von Harnack, Kline, Lewis, Tillich, Van Til, Plantinga, Polkinghorne, Moltmann, Bultmann, Heyns and Van Huyssteen, to mention but a few, and, of course, the publications of the theologians at their own universities, for instance, on ethics and morality. As averred at the beginning, education covers a multidimensional field of human activity, and the same applies to the science that investigates it. It would, therefore, be reasonable to assume that the educationists in the period under investigation would have read and consulted widely and deeply, including the works of theologians, ethicists and philosophers.

- As far as the educationists' reflection about philosophical theology is concerned, a sub-discipline of Philosophy, that branch of Philosophy that formally, systematically and scientifically examines a scholar's assumptive values, views and principles about God/the divine that might be playing a background role in how a particular scholarly discipline (such as Education) is approached, practised and understood, educationists, particularly those specialising in either the philosophy or the foundations of education, have over the years devoted time and attention to this aspect of their scholarship.

- Most educationists in the period under investigation seemed to have been conscious of the role that their personal 'theology' as informal, pre-scientific and pretheoretical aspect of their personal and social life and world views could (and should) fulfil in their scholarship. By far the majority of inhabitants of South Africa, and hence also of educationists, regard themselves as Christians, but they respond variously with regard to their Christian life and world views when confronted with educational or pedagogical issues. Scholars referred to as 'Christian reformational educationists' fully recognised and respected the role of their Christian life and world views in their scholarship. They consciously and deliberately acknowledged the role of their personal 'theology' (views and convictions regarding the divine in their lives and in the world), pertinently came to terms with this aspect of their scholarship and expressed their findings in their publications and in their tuition of students. It is for this reason that Van der Walt and Du Toit (1992:3) concluded that Coetzee, to name but one of these scholars, plied his trade as educationist 'on Biblical foundations', and that 'on reading his work, one soon realises that one is confronted 
with a true Christian believer, and as such (he) made a contribution to Christian-National Education'.

- Some of the educationists in this category used their Christian reformational life and world views to install CNE and to keep it in place.

- Other educationists were more concerned with critiquing $\mathrm{CNE}$ as part of their attack on the apartheid policies that were in place at the time.

- Another group, such as phenomenologists and positivists, attempted to 'bracket' their Christian life and world views in an effort to practise objective and even neutral Education science, but then attended to their life and worldviews as post-scientific manifestations of pedagogic categories. The latter group did not seem to acknowledge the integral and ingrained nature of their 'personal theology' as part of their personal life and world views.

\section{Provisional overall conclusion}

Much of what has been described above, particularly the conclusions drawn, will remain, in accordance with an interpretive-constructivist approach, tentative for the time being. More research is required to come to more pertinent conclusions. Based on the investigations reported in this article, it could be stated that Theology as a scholarly subject in its own right, and of equal scholarly standing as Education, seems not to have had momentous direction and formal impact on Education. Its impact on Education as a science was more of an indirect, informal, casual, interpersonal and subtle nature. The other two forms of 'theology', namely, philosophical theology and personal theology, arguably received much more attention from educationists in the course of practising their trade, and resultantly might have had a deeper and wider impact on their scholarly contributions.

\section{Acknowledgements Competing interest}

The author declares that he has no financial or personal relationships that may have inappropriately influenced him in writing this article.

\section{Author's contributions}

J.L.v.d.W. is the sole author of this research article.

\section{Ethical considerations}

This article followed all ethical standards for a research without direct contact with human or animal subjects.

\section{Funding information}

This research received no specific grant from any funding agency in the public, commercial or not-for-profit sectors.

\section{Data availability statement}

Data sharing is not applicable to this article as no new data were created or analysed in this study.

\section{Disclaimer}

The views and opinions expressed in this article are those of the author and do not necessarily reflect the official policy or position of any affiliated agency of the author.

\section{References}

Aldridge, D., 2018, 'Religious education's double hermeneutic', British Journal of Religious Education 40(3), 245-256. https://doi.org/10.1080/01416200.2018.1493267

Barnard, S.S. \& Coetsee, A.G., 1975, Onderwys aan Blankes in Transvaal, Pro Rege Publishers, Potchefstroom.

Barnard, S.S., 1976, Die Christenonderwyser: Roeping en Toerusting, Potchefstroom University, Potchefstroom.

Barnard, S.S., 1979, Blanke-onderwys in Transvaal: In histories-pedagogiese perspektief, Butterworth, Durban.

Bingle, H.J.J., 1953, 'Prof. Dr. Johannes Christiaan Coetzee as akademikus', Koers XX(5), 168-172.

Bingle, H.J.J., 1970, 'Ons lewens- en wereldbeskouing en Wet 39 van 1967', in R.J. Raath (ed.), ' $n$ Volk besin oor sy opvoeding en onderwys, pp. 24-31, Voortrekker Publishers, Cape Town.

Blackburn, S., 2017, Truth, Yale University Press, New Haven, CT.

Christie, P. \& Collins, C., 1984, 'Bantu Education: Apartheid Ideology and Labour Production', in P. Kallaway (ed.), Apartheid and Education. The education of black South Africans, pp. 161-183, Ravan Press, Johannesburg.

Coetzee, J.C., 1965, Inleiding tot die Algemene Teoretiese Opvoedkunde, J L van Schaik, Pretoria.

Coetzee, J.C., 1968, 'Christian national education', in R. Tunmer \& R.K. Muir (eds.), Some aspects of education in South Africa, pp. 16-30, University of the Witwatersrand, African Studies Programme, University of the Witwatersrand, Johannesburg.

Coetzee, J.C., n.d., Toepaslike Skrifgedeeltes vir huisbesoek, Faculty of Theology, Potchefstroom.

De Muynck, A., 2017, 'Christelijk pedagogiek: Bestaat het?', Radix 43(3), 120-131.

Department of Basic Education (South Africa), 2011, Curriculum and assessment policy statement. National Curriculum Statement, Government Printer, Pretoria.

Fowler, S., Van Brummelen, H. \& Van Dyk, J., 1993, Christian schooling: Education for freedom, Institute for Reformational Studies, Potchefstroom.

Hartshorne, K., 1993, Crisis and challenge. Black Education 1919-1990, Oxford University Press, Cape Town.

Jensen, C.B., 2019, Cosmopolitical perplexities: Pragmatic tests for changing climates, unpublished paper, viewed 12 April 2019, from https://www.academia. edu/38729958/Cosmopolitical_Perplexities_Speculative_and_Pragmatic_Tests for_Changing_Climates.

Labaree, D.F., 1998, 'Educational researchers: Living with a lesser form of knowledge', Educational Researcher 27(8), 4-12. https://doi.org/10.3102/ $0013189 \times 027008004$

Malan, C.J., 1986, Bybelse perspektiewe en relevante Skrifgegewens ten opsigte van opvoeding en onderwys, Department of Philosophy of Science, Potchefstroom.

Miedema, S., 2016, De spanningsvolle en potentieel complementaire relatie van pedagogiek en theologie, Lezing voor het Netwerk Pedagogie, Theologie en Onderwijs, 11 Mei 2016, network facilitated by the Driestar educatief, Gouda.

Nel, M., 2019, Life orientation for South African teachers, Van Schaik Publishers, Pretoria.

Nussbaum, M.C., 2011, Creating capabilities, The Belknap Press, Cambridge, MA.

Oosthuizen, I.J. (ed.), 2011, Aspects of education law, Van Schaik Publishers, Pretoria.

Packard, M.D., 2017, 'Where did interpretivism go in the theory of entrepreneurship?', Journal of Business Venturing 32, 536-549. https://doi.org/10.1016/j.jbusvent. 2017.05.004

Plotnitsky, A., 2006, 'Chaosmologies: Quantum field theory, chaos and thought in Deleuze and Guattari's What is Philosophy?', Paragraph 29(2), 40-56. https://doi. org/10.3366/prg.2006.0017

Schutte, B.C., 1978a, 'H J J Bingle en die stryd om Christelike opvoeding en onderwys', Koers 43(2), 102-105. https://doi.org/10.4102/koers.v43i2.1150

Schutte, B.C., 1978b, 'H J J Bingle se plek in die SA opvoedkundige panorama', Koers 43(2), 184-190. https://doi.org/10.4102/koers.v43i2.1164

Snyman, J.J., 1953, 'Prof J Chris Coetzee as opvoedkundige denker', Koers XX(5), 173-178. https://doi.org/10.4102/koers.v20i5.2011

Strauss, D.F.M., 2009, Philosophy. Discipline of the disciplines, Paideia Press, Grand Rapids, MI.

Taljaard, J.A.L., 1976, Polished Lenses, Pro Rege Press, Potchefstroom. 
Thanh, N.C. \& Thanh, T.T.L., 2015, 'The interconnection between interpretist paradigm and qualitative methods in education', American Journal of Educational Science $1(2), 24-27$.

Tripp, P.D., 2010, What did you expect?, Crossway, Wheaton, IL.

Van der Walt, B.J., 1999, Visie op die werklikheid, Institute of Reformational Studies, Potchefstroom.

Van der Walt, J.L., 1987, 'People's education': 'n model vir onderwys in 'n multikulturele samelewing [People's education: A model for education in a multicultural society], Human Sciences Research Council Research report, Potchefstroom University for Christian Higher Education.
Van der Walt, J.L., 2019, 'The collapse of the Berlin Wall in 1989: A historical turning point for South Africa, with reference to religion/religious education', in N. Popov, C. Wolhuter, L. De Beer, G. Hilton, J. Ogunleye, E. Achinewhu-Nworgu, et al. (eds.) C. Wolhuter, L. De Beer, G. Hilton, J. Ogunleye, E. Achinewhu-Nworgu, et al. (eds.),
Glocal education in practice: Teaching, researching, and citizenship, BCES Conference Books Volume 17, pp. 223-229, Bulgarian Comparative Education Conference Book
Society, Sofia.

Van der Walt, J.L. \& Du Toit, S.C., 1992, J Chr Coetzee: Reformatoriese opvoedkundige, Institute for Reformational Studies, Potchefstroom.

Van Zyl, P., 1970, 'Grondslae van ' $n$ Christelike opvoeding en onderwys', in R.J. Raath (ed.), ' $n$ Volk besin oor sy opvoeding en onderwys, pp. 62-83, Interkerklike Uitgewerstrust, Cape Town. 